\title{
Athymic Nude Mice as an Experimental Model for Cancer Treatment
}

\author{
I. SZADVARI ${ }^{1}$, O. KRIZANOVA ${ }^{1,2}$, P. BABULA $^{1,3}$ \\ ${ }^{1}$ Department of Physiology, Faculty of Medicine, Masaryk University, Brno, Czech Republic, \\ ${ }^{2}$ Institute of Clinical and Translational Research, Biomedical Research Center, Slovak Academy of \\ Sciences, Bratislava, Slovakia, ${ }^{3}$ International Clinical Research Center, St. Anne's University \\ Hospital Brno, Brno, Czech Republic
}

Received September 26, 2016

Accepted October 27, 2016

\section{Summary}

Athymic nude mice, a murine strain bearing spontaneous deletion in the Foxn1 gene that causes deteriorated or absent thymus (which results in inhibited immune system with reduction of number of $\mathrm{T}$ cells), represent a widely used model in cancer research having long lasting history as a tool for preclinical testing of drugs. The review describes three models of athymic mice that utilize cancer cell lines to induce tumors. In addition, various methods that can be applied in order to evaluate activity of anticancer agents in these models are shown and discussed. Although each model has certain disadvantages, they are still considered as inevitable instruments in many fields of cancer research, particularly in finding new drugs that would more effectively combat the cancer disease or enhance the use of current chemotherapy. Finally, the review summarizes strengths and weaknesses as well as future perspectives of the athymic nude mice model in cancer research.

\section{Key words}

Athymic nude mice $\bullet$ Cancer $\bullet$ Experimental models • Anticancer treatment $\bullet$ Xenograft

\section{Corresponding author}

P. Babula, Department of Physiology, Faculty of Medicine, Masaryk University, Kamenice 5, 62500 Brno, Czech Republic. E-mail: babula@med.muni.cz

\section{Cancer diseases and their treatment}

Cancer is one of the most serious diseases and still one of the leading causes of both mortality and morbidity in a population. It represents a potential source of severe health complications that may be permanent, thus bringing burden not only to the afflicted individual, but also to the family and society as well. Incidence and mortality of different types of cancer can be influenced by several factors, e.g. socioeconomic status, different already well-defined cancer risk factors (e.g. diet, smoking, alcohol, exogenous hormonal use), but also other largely unknown factors playing role in these relationships (Weiderpass and Pukkala 2006). Up to now, more than 200 different types of cancer were described. Malignant tumors can be classified according to various parameters, for example their biological behavior (e.g. rate of growth, hypoxic status, aggressiveness, readiness to metastasing), tissue of origin (solid tumors and those derived from blood tissue), histological type (carcinomas, adenocarcinomas, sarcomas, etc.) or responsiveness to a chemotherapy. Some tumors tend to be chemosensitive, others might exhibit more or less resistance due to several factors or combinations of these factors, such as drug inactivation, drug target alteration, drug efflux, autophagy, etc. (Housman et al. 2014, van der Wekken et al. 2016, Farrow et al. 2014).

Various tumors can also differ in hypoxic status and prognosis. Hypoxia increased ability of malignant cells to survive, and also to migrate, invade and metastasize. Moreover, hypoxic cells exhibit therapyresistance. Thus, tumor cells growing in the hypoxic conditions might survive and account for more invasive and metastatic behavior of the tumor. One of the components that can contribute to occurrence of these 
phenomena is the carbonic anhydrase IX (CA IX) that is expressed only in hypoxic tumor cells. Presence of the CA IX worsens the overall prognosis, but on the other hand makes a promising target for an effective therapeutic agent (Pastorek and Pastorekova 2015, Kumari et al. 2016). Prognosis of a certain type of cancer is dependent on many other factors, like its histological type, location, certain specific traits, chemosensitivity, age of the patient, comorbidities. The best prognosis with a highest 5-year relative survival (5-y-RSC) exhibit testicular cancer $(88.6 \%)$, lip cancer $(88.1 \%)$ and thyroid cancer $(86.5 \%)$, as determined by population based study of cancer survival EUROCARE-5 (De Angelis et al. 2014). However, there are some tumors that have propensity for being clinically silent, or they have symptoms similar to other diseases up to the point, where they will invade neighboring tissues and organs or form distant metastasis. Prognosis of such tumors is generally poor. Rapidly fatal cancers like lung, oesophagus, liver, pleura and pancreas cancer can serve as examples (De Angelis et al. 2014, Seicean et al. 2015). Consequently, it is necessary to further develop new biomarkers for screening as a secondary prevention of cancer, such as micro-RNAs, DNA, RNA, DNA methylation patterns or new protein markers and introduce them to clinical practice (Dhaliwal et al. 2015, Majumder et al. 2015, Oh et al. 2015).

Table 1. Examples of some commonly used anticancer chemotherapeutics and their mechanism of action.

\begin{tabular}{|c|c|c|}
\hline Therapeutic agents & Mechanism of action & Reference \\
\hline Bleomycin & $\begin{array}{l}\text { - produces oxidative cleavage of DNA and possibly RNA } \\
\text { - mediates degradation of DNA, mRNAs, and active chromatin } \\
\text { - causes G2 arrest, inhibition of DNA and RNA synthesis and induces apoptosis }\end{array}$ & $\begin{array}{l}\text { Bimonte et al. 2015, van } \\
\text { der Kuyl et al. } 2002\end{array}$ \\
\hline Capecitabine & $\begin{array}{l}\text { - is a prodrug converted in both tumor and normal tissues to the active drug fluorouracil } \\
\text { ( } 5 \text {-FU) } \\
\text { - higher concentration of the conversion enzyme is found in cancer cells and liver }\end{array}$ & $\begin{array}{l}\text { Walko and Lindley } \\
2005\end{array}$ \\
\hline Cyclophosphamide & $\begin{array}{l}\text { - its cytotoxic effect lies in the cross-linking of DNA strands and subsequent inhibition of } \\
\text { cell division } \\
\text { - in addition, it possesses immunomodulatory anticancer effects }\end{array}$ & $\begin{array}{l}\text { Le and Jaffee } 2012 \text {, } \\
\text { Mukhtar and } \\
\text { Woodhouse } 2010\end{array}$ \\
\hline Doxorubicin & $\begin{array}{l}\text { - intercalation into DNA (causes inhibition of DNA and RNA polymerases) and inhibition } \\
\text { of topoisomerase II mediated DNA repair in the process of removing DNA supercoiling } \\
\text { - free radical generation which causes damage to DNA, cellular membranes and proteins } \\
\text { - other possible mechanisms are involved }\end{array}$ & $\begin{array}{l}\text { Thorn et al. 2011, } \\
\text { Pommier 2013, Tacar et } \\
\text { al. } 2013\end{array}$ \\
\hline Fluorouracil & $\begin{array}{l}\text { - is a pyrimidine analogue which interferes with DNA synthesis and repair via inhibition } \\
\text { of thymidylate synthase (exerts so called thyminless death) } \\
\text { - affects normal function of nucleic acids via misincorporation into DNA and RNA } \\
\text { - other possible mechanisms have been proposed (e.g. cell cycle regulation interference, } \\
\text { inhibition of angiogenesis, etc.) }\end{array}$ & $\begin{array}{l}\text { Zhang et al. 2008, } \\
\text { Wyatt and Wilson } 2009\end{array}$ \\
\hline Gemcitabin & $\begin{array}{l}\text { - is an analogue of deoxycytidine that induces apoptosis via inhibition of DNA base } \\
\text { synthesis and by incorporation into DNA, thus, precluding DNA synthesis }\end{array}$ & Mini et al. 2006 \\
\hline Hydroxyurea & $\begin{array}{l}\text { - inhibition of DNA synthesis via inhibition of ribonucleotid reductase (enzyme } \\
\text { responsible for the synthesis of deoxyribonucleotides) }\end{array}$ & $\begin{array}{l}\text { Torrents 2014, Yarbro } \\
1992\end{array}$ \\
\hline Irinotecan & $\begin{array}{l}\text { - inhibition of topoisomerase-1, and consequent DNA breaks occur } \\
\text { - induction of G2 arrest/delay and cell death }\end{array}$ & $\begin{array}{l}\text { Xu and Villalona-Calero } \\
2002\end{array}$ \\
\hline Metothrexate (MTX) & $\begin{array}{l}\text { - belongs to the category of drugs called antifolates } \\
\text { - inhibits conversion of dihydrofolate to tetrahydrofolate which is necessary for the } \\
\text { synthesis of nucleotides, particularly thymidine. Thus, DNA and RNA synthesis is } \\
\text { inhibited }\end{array}$ & $\begin{array}{l}\text { Wong and Choi } 2015, \\
\text { Schweitzer et al. } 1990 \\
\text { Bleyer } 1978\end{array}$ \\
\hline Oxaliplatin & $\begin{array}{l}\text { - mechanism of action similar to other platinum-based substances like cisplatin } \\
\text { - predominantly causes DNA damage (by inter-/intra-strand crosslinking) } \\
\text { - other effects include: DNA/mRNA synthesis arrest, and inducing cytotoxic immunologic } \\
\text { mechanisms }\end{array}$ & $\begin{array}{l}\text { Alcindor and Beauger } \\
2011\end{array}$ \\
\hline Paclitaxel (Pac) & $\begin{array}{l}\text { - interferes with microtubule dynamics by its stabilizing effect on the assembly of } \\
\text { microtubules } \\
\text { - leads to defective chromosome segregation and blocks cell cycle completion } \\
\text { - exerts inhibitory effect on microtubule fragment formation at centrosomes }\end{array}$ & Ganguly et al. 2010 \\
\hline Vinblastine (Vinb) & $\begin{array}{l}\text { - another tubulin targeting drug like Pac - interference with microtubule dynamics via } \\
\text { inhibition of microtubule assembly } \\
\text { - exerts positive effect on microtubule fragment formation at centrosomes }\end{array}$ & Ganguly et al. 2010 \\
\hline
\end{tabular}


Although origin of tumor's induction is not yet fully understood, several factors are known to be responsible for initiation of the malignant degeneration of a cell. Among these are sporadic mutations of the genome, radiation and various chemical mutagens responsible for tumorigenesis, etc. Also, biological factors such as Epstein-Barr virus or Helicobacter pylori are known to play a role in the initiation of cancerogenesis (Geng and Wang 2015, Testerman and Morris 2014). In some cases, an individual can inherit familial predisposition to cancer. Such tumors then occur generally in an early phase of life, e.g. in childhood. In addition, several risk factors have been identified that are associated with the multistep process of cancerogenesis, including obesity, smoking, alcohol, or stress. Therapy of cancer is based on the utilization of various modalities, and chemotherapy represents one of the basic approaches applied in the treatment. Targets of various chemotherapeutic agents differ and comprise different intracellular pathways, processes and components of malignant cells, which together participate in the expression of the cell's carcinogenic potential. They can affect the cell cycle, or regulate apoptosis of cells with many structural defects in DNA that are responsible for angiogenesis and spread of the cancer to other tissues and organs (Table 1). Nevertheless, research of new potent anticancer drugs that might target novel cellular pathways is still crucial and proper in vitro, and in vivo models are inevitable requirements for preclinical studies.

\section{Athymic nude mice as the first experimental model in cancer research}

Anticancer drugs tested on cell cultures in vitro are often not transferable to conditions, in which tumors grow in humans, due to the lack of appropriate tumor microenvironment, which is common to tumor's development and interaction during growth (e.g. vascularization issues, human immune system, etc.) (Shultz et al. 2014, Boone et al. 2015). Preclinical phase of cancer research needs to include in vivo models that mimic at least to some extent the clinical situation in a human organism, and are essential as a part of preclinical anticancer drug testing (Stakleff and Von Gruenigen 2003).

The first description of athymic nude mice was presented by Flanagan in 1966 in UK after their discovery in the stock of albino mice in Virus Laboratory of Ruchill Hospital in Glasgow, UK in 1962. Flanagan
(1966) first described both their phenotypical and genetic traits, and assigned the effect of visible lack of hair to a new recessive gene (localized on the chromosome 11), which he called nude (the abbreviation of which is nu, often used to describe the gene or the allele combination $n u / n u$; Fig. 1). Later, research has shed more light into the molecular biology, morphological, and immunological characteristics of the nude mice (Mecklenburg et al. 2005).

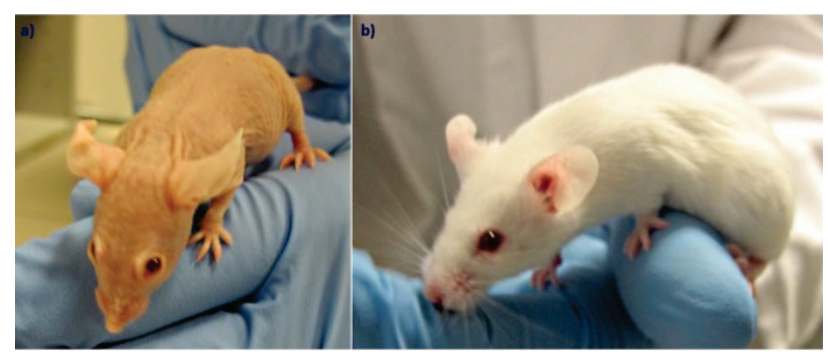

Fig. 1. Comparison of mice with homozygous and heterozygous mutation. (a) nude female homozygote (nu/nu), (b) nude female heterozygote $(\mathrm{nu} /+)$ (both around 7 weeks of age).

The most important trait of mice pertaining to the utilization in cancer research is their lack of thymus (Pantelouris 1973). Specific T-cell- mediated type of immunity is responsible for destroying infected cells (e.g. by viruses), or malignant cells. The T-lymphocytes are further responsible for the host versus graft reaction (so called HVGR), which occurs when a transplant (both allo- or xeno-) is being rejected by a host (Cadili and Kneteman 2008, Ruiz et al. 2013). Deficiency of T-lymphocytes considerably immunocompromises the mice and enables the engraftment, growth and eventually metastasizing of the tumor cells from the xenograft after the implantation (Stakleff and Von Gruenigen 2003, Sun et al. 2014).

Macroscopically, the skin of athymic nude mice seems to be hairless (Fig. 1). In reality, it contains normal hair follicles at birth, but later, as the hair shaft grows, it starts to coil within the infundibulum and fails to penetrate the epidermis (Flanagan 1966, Mecklenburg et al. 2005). The genetic background behind this phenomenon was revealed to be a spontaneous loss-offunction mutation resulting in a recessive homozygozity in the locus of FoxN1 (Forkhead box, previously called Whn or Hfh11) gene, encoding transcription factors (Mecklenburg et al. 2005). Heterozygotes do not exhibit any visible phenotypical changes (Fig. 1). It is known that there are some minor deviations regarding the 
thymus size and immune response in comparison to healthy mice (Holub 1992).

Another phenotypical traits of the athymic nude mice are their retarded growth, reduced fertility, absence of vibrissae at birth, and limited life span of the majority of mice due to general body weakness (Flanagan 1966). Under normal housing conditions the athymic nude mice will live ranging from 6 months up to one year. Although both, viability and fertility are severely diminished, they can be enhanced when mice are bred under specific germfree conditions, whereby their life span can be increased to that of a normal mouse (which is from 18 months to 2 years). Since athymic nude mice have underdeveloped mammary glands and are unable to effectively nurse their offsprings, athymic nude males are bred with heterozygous females (Holub 1992).

Although in athymic nude mice the thymic primordium that is formed by epithelial precursor cells normally develops, its maturation into the mature thymus is defective (Prowse et al. 1999). The interplay between different autocrine and paracrine regulatory signaling molecules, their receptors and corresponding intracellular pathways, is necessary for the normal thymic and T-lymphocyte development and function, such as tumor necrosis factor receptor (TNFR), transmembrane protein receptor CD40, etc. (Sun et al. 2014). With the absence of Foxn1 protein due to $n u / n u$ recessive mutation, both differentiation and proliferation of thymic epithelial cells (TECs) and progenitors of T-lymphocytes are defective. The TECs play a crucial role in the T-lymphocyte maturation. Other functions of Foxn1 protein by which it influences T-cells, are vascularization of the thymus, its colonization by T-cell progenitors, and their selection. Mechanism of action lies in regulating series of genes that encode molecules involved in thymic development and function, like Pax1 (paired-box1), CCL25 (Chemokine (C-C Motif) Ligand 25), etc. (Sun et al. 2014).

The model of the athymic nude mice has certain limitations, since the immunodeficiency is severe, but not absolute. Despite the fact that there are only few $\mathrm{T}$ cells in the periphery, the intact innate immunity, particularly high NK cell's activity can limit the engraftment take rate (i.e. percentage of successfully engrafted tumors), growth, and ability to form metastasis of the majority of primary solid tumors, and makes the engraftment of malignant hematopoietic cells impossible (Shultz et al. 2005, Shultz et al. 2014). These issues could be resolved by using other types of immunodeficient mice, where NK cell activity is decreased or even absent (Shultz et al. 2005, Shultz et al. 2014). Since activity of T-cells tends to increase with the age, it is appropriate to use younger mice (usually 5-10 weeks of age) to enhance the engraftment rate, and thus, reproducibility of the studies (Giovanella and Fogh 1985, Liu et al. 2015, Pacak et al. 2012).

Despite these hindrances, the athymic nude mice have been successfully used as a host for tumor cells and represent a suitable model for studying the behavior of cancer in vivo, such as engraftment, growth, invasion and metastasis. The main advantage of this model lies in the natural immunosuppression of mice. It is relatively simple to achieve engraftment of a desired type of tumor by simply inoculating the cancer cells into the animal host. Variety of common established tumor cell lines is used for inoculation. Another advantage is that the tumor can be easily observed in athymic nude mice when injected subcutaneously due to the natural lack of hair. Recently, the patient derived models (PDX) are being discussed, since they more genuinely mimic the microenvironment and behavior of the primary tumor (i.e. response to chemotherapeutics) (Boone et al. 2015). Moreover, they allow determination and better prediction of efficacy of biomarkers that could be useful for cancer diagnostics and prognosis assessment (Boone et al. 2015, Hidalgo et al. 2014, Marangoni and Poupon 2014). However, PDX are cost-ineffective and it takes a long time until a visible tumor can be observed in the mice. Most patients cannot afford to wait until their tumor model is tested for the drug response. In addition, various immunomodulators cannot be tested on this model since athymic nude mice lack the proper immune response that take place at the site of the primary tumor in human organism (Boone et al. 2015, Gazdar et al. 2015, Tentler et al. 2012).

Since immunodeficiency of athymic nude mice allows engraftment of stem cells, these mice can also be used in the field of stem cell research (Jang et al. 2016, Rodriguez et al. 2015). There are several types of mutant variants of mice that carry the nude gene mutation available in various laboratories. These ,nude mice variants" have been produced by crossing other strains of mice (such as Balb/c, CD-1 or NMRI) with athymic nude mice. As already mentioned, either stable cancer cell lines, or cancer cells taken directly from the patient (PDX model) could be used to introduce the tumor into the mice, with both methods having their strengths and weaknesses. 
Up to now, several new murine strains of immunodeficient mice were developed. Spontaneous mutation in C.B17 mice, termed scid (Prkdc scid, protein kinase DNA activated catalytic polypeptide), largely prevents the development of mature $\mathrm{T}$ and $\mathrm{B}$ lymphocytes of the adaptive immune system. The first example of severe combined immunodeficiency (SCID) not primarily related to a hematopoietic cell abnormality but rather to an intrinsic thymic epithelial cell defect is the Nude/SCID phenotype, whose identification contributed to unravel important issues of $\mathrm{T}$-cell ontogeny (Romano et al. 2012). The term "SCID" has now been adapted to refer to all severely immunodeficient strains of mice, including those expressing the Rag1 $1^{\text {null }}$ or $\operatorname{Rag} 2^{\text {null }}$ mutations (Shultz et al. 2014).

A major leap forward in the engraftment of primary human cells, tissues, and tumors was the development of immunodeficient mice bearing a targeted mutation in the IL2-receptor common gamma chain gene $\left(I L 2 r g^{\text {null }}\right)$. When combined with the scid, Ragl $1^{\text {null }}$, or $\operatorname{Rag} 2^{\text {null }}$ mutations, a mouse completely deficient in adaptive immunity and severely deficient in innate immunity is generated that is highly receptive to engraftment of human cells, tissues, and primary tumors (Shultz et al. 2007, Shultz et al. 2012).

Genetically modified organisms, especially genetically engineered mice (GEM), are also used in the study of genetic and molecular mechanisms of disease, often with the aim of developing treatments and interventions to improve health and longevity (Brayton et al. 2012).

\section{Cell lines - a potent tool for tumor development in athymic nude mice}

History of the cell lines used in cancer research dates back to the first stable cell line successfully isolated and distributed throughout the whole world. The HeLa cell line (as it was called after the patient Hentrietta Lacks from whom the tumor cells were harvested), prepared from the cells from cervical cancer (Lucey et al. 2009) and it was able to divide unlimited number of times when being grown under certain living conditions. This effect is due to the upregulation of telomerase activity in more than $90 \%$ percent of cancer cells or by alternative pathways, all of which lead to maintaining the length of telomeres (Carnero et al. 2015). Immortalized cells form the basis of preclinical cancer research and studies represent one of the important sources of our current knowledge of the biology of cancer. More than one hundred and twenty cultured human tumor cell lines produced tumors after subcutaneous inoculation of 1-20 million cells into nude mice (Fogh et al. 1977). The histopathology of tumors developed in mice correlated with the human tumor of origin in all cases.

Various cancer types of different organ, tissue, and histological origin can be isolated and maintained as a homogenous culture of the tumor cells with both genotypical and phenotypical expression profile of the primary tumor (Hwang et al. 2016). Homogeneity of the culture is of advantage since cells are uniform (both genotypically and phenotypically), and lack the cellular variability that exists in a primary tumor. Uniformity together with the immortality enables research of metabolic pathways participating in the cancerogenous process, identification of oncogenes and tumor suppressor genes, and various mutations that occur in the malignant cells, including diagnostic and therapeutical options in cancer treatment, without being limited by the durability of the cell culture (Gazdar et al. 2015). For example, effective novel drug screens can be performed on various tumors, or new biomarkers can be defined determining the prognosis or drug response according to adherence of patients to different subgroups (Hwang et al. 2016, Jeon et al. 2014, Collisson et al. 2011). Moreover, this method is relatively cost-effective, since the cell lines can be maintained by cryopreservation and passaging.

Certain disadvantages are connected with the utilization of established cancer cell lines, though. Cell lines alone might not always be suitable tool for cancer research or testing efficacy of anticancer agents (Boone et al. 2015, Gazdar et al. 2015). Even though genetic changes that occurred in the primary tumor may be maintained throughout the subsequent generations of the cell lines, there might be some genomical and phenotypical modification from the primary cells that have been harvested decades ago. This factor must be taken into the consideration since it might affect results of the preclinical anticancer drug testing (Boone et al. 2015). Moreover, cell cultures lack the heterogeneity of tumor cells (some cell lines may only represent a clone that was selected and preferentially grows in the artificial setting in vitro, but not in a real in vivo conditions) and also interactions with stromal microenvironment present in the primary tumor (Boone et al. 2015). This adds a barrier to the research of cancer therapy targeted against the immune cells and vasculature of the tumor in vivo (Gazdar et al. 2015). 
Nevertheless, established cancer cell lines are still a useful and indispensable tool in cancer research, but the above-mentioned limitations must be taken into the consideration. As a result, in vivo models such as immunodeficient mice need to be included into preclinical research, where constitutional cancer cell lines can be implanted as xenografts into the mice (Gazdar et al. 2015, Stakleff and Von Gruenigen 2003). Further, we will focus on summarizing various procedures of inducing a tumor using stable cell lines as a xenograft, and ways of evaluating the tumor growth after treatment.

\section{Models of tumor induction in athymic nude mice}

Various murine models have been used to gain insight into the pathophysiology of cancer, and they serve as an in vivo instrument in preclinical testing of various treatment modalities and diagnostic strategies. The basic feature of all these models is their suppressed immunity. Because of their immunodeficiency and ability to tolerate cancer xenografts, athymic nude mice represent a widely used murine model for inducing different types of cancer. The nude mutation prevents development of functional T-cells and provided an early model for engraftment of human cell lines derived from solid tumors (Fogh et al. 1977). However, these mice bear some limitations due to presence of humoral adaptive immune system and also an intact innate immune system.

Since the nude mice are still a valid model utilized as a tool in the preclinical phase of testing new drugs (particularly as a second step to confirm the effect of drug's activity that was observed in vitro) (Burkhart et al. 2014, Rouleau et al. 2015), and also conventional therapy in various new forms, combinations, or for drug resistance (Guo et al. 2016, Yeon Kim et al. 2016, Burkhart et al. 2014), it will be useful to summarize various methods used to develop a tumor and describe different possible endpoints of the treatment. Three basic models of a tumor induction include orthotopic, heterotopic, and metastatic model (Fig. 2) (Schuh 2004, Shaw et al. 2004). In the orthotopic model, cells are either surgically implanted or injected into the site of the tumor's origin. In the heterotopic model, cells are injected into a subcutaneous space (s.c.). Both these methods have their strengths and weaknesses, pertaining to simplicity, relevance, or tumor engraftment rate (Stakleff and Von Gruenigen 2003). In the metastatic model, the tumor cells are injected either into the lateral tail vein of the mouse or intra-cardially (i.e. into the left ventricle) (Khanna and Hunter 2005). Cells will disseminate into the body forming lesions in various organs. In addition, the metastatic model can also be established by intraperitoneal (i.p.) injection, intraosseal injection (into tibia or femur), intrasplenic injection or electing other intravenous routes (for reviews see (Saxena and Christofori 2013, Simmons et al. 2015, Bollard et al. 2013).

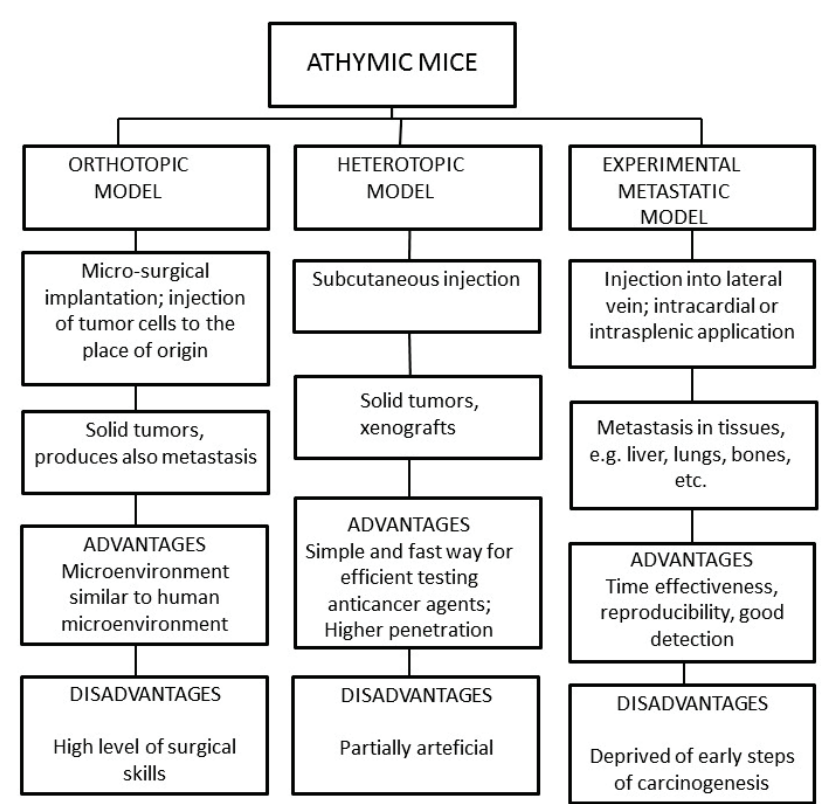

Fig. 2. Schematic diagram of three models of cell's injection into athymic nude mice.

Subcutaneous heterotopic model is the most common one due to its relative simplicity in design and evaluation (the hairlessnes of mice enables the growth of the tumor to be observed with the naked eye). It has been therefore utilized as a model enabling rapid screening of various new compounds (Killion et al. 1998). Suspension of tumor cells is standardly injected into the right or left flank of mice (or both at the same time), but other sites can be elected as well (Schuh 2004). The appropriate amount of cells should be used to establish a tumor, since small amounts of cells can result in unsuccessful engraftment and growth of the xenograft (Fogh et al. 1977). The usual number of cells required to produce a solid tumor is in the order of $10^{6}$ (injected usually in $0,1 \mathrm{ml}$ cell suspension), but the exact number depends on the specific cancer cell line that is utilized and viability. The tumorigenicity and metastasis formation of xenografted cell lines can be further enhanced by coinjection of a reconstituted basement membrane matrix (Matrigel) (Bao et al. 1994). 
Once the cells are inside the host, it usually takes from two to six weeks until the tumor becomes visible and measurable. Exact time depends on a cell line's type, interaction with the host, and the site chosen for the inoculation (Schuh 2004, Dipersio 1981). It is likewise important to check or evaluate the cancer cell line's take rate. As it was already mentioned, some cell lines do not produce tumors in athymic nude mice at all, and others might be difficult to engraft, e.g. CAKI1 clear cell carcinoma cell lines (Niu et al. 2012). The growth of the s.c. xenograft is usually measured 2 or 3 -times a week by a caliper, preferably by the same person (Workman et al. 2010). The two distances (diameters) at right angles are measured, i.e. the width (w) - which is the greatest transverse diameter, and a length (l) - the greatest longitudinal diameter) (Pacak et al. 2012, Nölting et al. 2014). These parameters encode either the tumor surface area or volume (most commonly $l x w$ for tumor area and modified formula for elipsoid $1 / 2\left(l x w^{2}\right)$ for tumor volume) (Tomayko and Reynolds 1989, Rahal et al. 2015).

Two basic approaches in verification of the efficacy of a chemotherapeutic agent can be studied. To prove that a certain drug exerts a chemopreventive effect on a tumor, the initiation of the treatment should start before the cell injection, or no later than the cell injection (Singh et al. 2004, Nölting et al. 2014). Secondly, either cytostatic (i.e. growth delay) or cytotoxic (tumor volume shrinkage) effect on an already growing tumor could be evaluated, where the treatment is given with a time delay (several days to weeks depending on how fast the xenografts grow) following the inoculation of the cells (Kelland 2004). Mostly, the therapeutical substance is applied as an oral gavage (Ellinghaus et al. 2013) or by i.p. injection (Yang et al. 2016). Other modes of applications are possible as well, such as subcutaneous (Kenmogne et al. 2015), intratumoral (Jiang et al. 2016), intravenous (tail vein, portal vein, etc.) or intraarterial (carotid artery) (Kim et al. 2016).

At the end of treatment, animals are sacrificed, tumors are extracted and weighed (Wang et al. 2016). To evaluate the potential anticancer activity of a substance, various endpoints can be set, such as a change in tumour growth rate, growth delay, cell survival (clonogenic assay), or levels of appropriate surrogate marker, e.g. proliferation marker KI-67 (Haddad and Yee 2008, Workman et al. 2010). Most commonly, the terminal weight of the tumor in the control and treated group can be compared. Also, curve of either the tumor volume or area at different time points during experiment are commonly demonstrated (Wang et al. 2016, Ellinghaus et al. 2013), or the delay with which the treated group reaches a determined tumor size (Teicher 2006). The tumor growth can be also monitored using bioluminescence or fluorescence of the tumor cells (e.g. the cells that are stably transfected with a vector expressing light emitting enzyme, such as luciferase (Luc) or the green fluorescent protein (GFP), respectively) (Hoffman 2015, Simmons et al. 2015, Nölting et al. 2014). Various other modalities affected by the treatment can be studied in addition to the tumor growth, such as induction of apoptosis (Hui et al. 2015, Kim et al. 2012, Archana et al. 2013, Ma et al. 2014), or inhibition of angiogenesis (Yin et al. 2016, Ma et al. 2014). Finally, inhibition of the occurrence/growth of spontaneous metastasis can be evaluated, although the s.c. tumors are known to form metastasis less frequently, and there are more appropriate models available (Khanna and Hunter 2005).

Advantage of the experimental metastatic model lies in its time-effectiveness (rapid development of tumors), reproducibility and consistency (Khanna and Hunter 2005). In the case of peritoneal carcinomatosis model, the time period until the tumor becomes palpable may be longer (Yao et al. 2015). The tumor growth can be measured in vivo by either bioluminiscence or fluorescence. Other methods include magnetic resonance imaging (MRI), computed tomography (CT), positron emission tomography (PET), single photon emission computed tomography (SPECT) imaging, or radiography (Simmons et al. 2015, Khanna and Hunter 2005). The election of the specific method is directed by its availability, resolution, speed of imaging or throughput, and cost (Simmons et al. 2015).

After treatment, the tumors can be evaluated in the organs or tissues selected by the frequency of the occurrence of the metastasis (e.g. in tail vein model - it is often the liver, because of the first capillary bed), but other sites, such as lungs are targeted as well (Khanna and Hunter 2005). In the intracardial model, the most frequent metastatic sites are determined by the tumor type; e.g. bone and lung in prostatic tumors (Bubendorf et al. 2000) or lung, bone, and liver in breast tumors (Weigelt et al. 2005). Consequently, in vivo or ex vivo imaging (the intensity of signal or number of lesions), gross anatomy (the number of macroscopic lesions), histopathology or immunohistochemistry (i.e. number of the tumors in selected sections, inhibition of 
angiogenesis, detection of apoptosis, or proliferation index) of the tumors can be performed (Pacak et al. 2012, Nölting et al. 2014, Wang et al. 2016). In addition, the terminal weight of the tumors or survival rate of both groups can be compared (Khan et al. 2015, Shaw et al. 2004). Pertaining to the intraperitoneal model, difference in the number and weight of the intraperitoneally growing tumorous nodules may be assessed (Yao et al. 2015).

Although the subcutaneous and experimental metastatic model represents relatively a simple and fast way to determine the efficacy of anticancer agents, both of these models have their drawbacks, since they do not exactly reflect clinical scenario of the primary tumor (Khanna and Hunter 2005). The reason is particularly the lack of the microenvironment, where the primary tumors develop allowing the proliferation of specific tumor subclones, and thus modifying the behavior of the tumor as a whole. Moreover, experimental metastatic models are deprived of the early steps of carcinogenesis, and the structure of metastatic emboli formed in the blood stream differs from the one that we observe in in the tumors metastasizing spontaneously (Khanna and Hunter 2005, Stakleff and Von Gruenigen 2003, Killion et al. 1998). On the contrary, the microenvironment of the murine organ contributes to the development of the tumor similarly as the human microenvironment. In addition, orthotopic models more frequently produce metastasis spontaneously than the subcutaneous. Khanna and Hunter (2005) include specific examples of cell lines that are useful in spontaneous metastasis essays. Also, it has been estimated that responses of anticancer drugs in the orthotopic model correlate more with the activity seen in the clinical practice (Hoffman 1999). The orthotopic model is therefore generally considered to be more appropriate for studying tumor behavior, performing pharmacologic studies, and developing diagnostical procedures (Hoffman 1999).

To establish the orthotopic model, the cells can be introduced either by direct injection or by microsurgical implantation (SOI) to the organ of the tumor's origin. It has been shown that tumors formed by the direct injection exhibit lower rates of metastasis and differ in tissue architecture from the primary tumor in comparison to SOI implantation of the tumor fragments. In SOI, usually $1 \mathrm{~mm}^{3}$ of tumor tissue is used for implantation, and the cells are taken either directly from the patient or the subcutaneous xenograft grown in athymic nude mice (He et al. 2015, Scott et al. 2014, Hoffman 1999). When using direct injection, the approximate number of cells does not differ from other models (Greco et al. 2016, Xiong et al. 2015, He et al. 2015). Various organ specific orthotopic models have been already developed, and new drugs have been successfully tested (Killion et al. 1998, Hoffman 1999). The endpoints used for evaluation of treatment efficacy are essentially the same, and they include inhibition of primary tumor growth, inhibition of metastatic events, extension of survival, or decrease in cachexia. The model is seen as a bridge from preclinical testing to the clinical practice, though it has certain limitation requiring high level of surgical skills for tumors to be correctly implanted (Hoffman 1999).

\section{Conclusions}

Athymic nude mice are a widely used murine model due to its relative simplicity and cost-effectivity, and has a long history as a tool for preclinical testing of drugs (Croy et al. 2001, Meyerrose et al. 2003). Here we have described three models that utilize cancer cell lines to induce tumors in athymic nude mice, various methods that can be applied in order to evaluate the activity of anticancer agents as well as their strengths and weaknesses. Although each of the models might have certain disadvantages, they are still considered as inevitable instruments in many fields of cancer research, particularly in finding new drugs that would more effectively combat the cancer disease or enhance the use of current chemotherapy (Killion et al. 1998). Novel mice strains with highly suppressed immune system (SCID, GEM, etc.) will enhance the effectivity of anticancer drug testing.

\section{Conflict of Interest}

There is no conflict of interest.

\section{Acknowledgements}

This publication was written at Masaryk university as a part of the project "Kardiovaskulární systém: od modelu přes terapii k prevenci“, number MUNI/A/1365/2015 with the support of the Specific University Research Grant, as provided by the Ministry of Education, Youth and Sports of the Czech Republic in the year 2016 and, likewise, supported by the project No. LQ1605 from the National Program of Sustainability II (MEYS CR). Work of O.K. is supported by grant VEGA 2/0082/16. 


\section{References}

ALCINDOR T, BEAUGER N: Oxaliplatin: a review in the era of molecularly targeted therapy. Curr Oncol Tor Ont 18: 18-25, 2011.

ARCHANA M, BASTIAN, YOGESH TL, KUMARASWAMY KL: Various methods available for detection of apoptotic cells--a review. Indian J Cancer 50: 274-283, 2013.

BAO L, MATSUMURA Y, BABAN D, SUN Y, TARIN D: Effects of inoculation site and Matrigel on growth and metastasis of human breast cancer cells. Br J Cancer 70: 228-232, 1994.

BIMONTE S, LEONGITO M, BARBIERI A, DEL VECCHIO V, BARBIERI M, ALBINO V, PICCIRILLO M, AMORE A, Di GIACOMO R, NASTO A, GRANATA V, PETRILLO A, ARRA C, IZZO F: Inhibitory effect of (-)-epigallocatechin-3-gallate and bleomycin on human pancreatic cancer MiaPaca-2 cell growth. Infect Agent Cancer 10: 22, 2015.

BLEYER WA: The clinical pharmacology of methotrexate: new applications of an old drug. Cancer 41: 36-51, 1978.

BOLLARD J, COUDERC C, BLANC M, PONCET G, LEPINASSE F, HERVIEU V, GOUYSSE G, FERRAROPEYRET C, BENSLAMA N, WALTER T, SCOAZEC JY, ROCHE C: Antitumor effect of everolimus in preclinical models of high-grade gastroenteropancreatic neuroendocrine carcinomas. Neuroendocrinology 97 : 331-340, 2013.

BOONE JD, DOBBIN ZC, STRAUGHN JR. JM, BUCHSBAUM DJ: Ovarian and cervical cancer patient derived xenografts: The past, present, and future. Gynecol Oncol 138: 486-491, 2015.

BRAYTON CF, TREUTING PM, WARD JM: Pathobiology of aging mice and GEM: background strains and experimental design. Vet Pathol 49: 85-105, 2012.

BUBENDORF L, SCHÖPFER A, WAGNER U, SAUTER G, MOCH H, WILLI N, GASSER TC, MIHATSCH MJ: Metastatic patterns of prostate cancer: an autopsy study of 1,589 patients. Hum Pathol 31: 578-583, 2000.

BURKHART C, FLEYSHMAN D, KOHRN R, COMMANE M, GARRIGAN J, KURBATOV V, TOSHKOV I, RAMACHANDRAN R, MARTELLO L, GUROVA KV: Curaxin CBL0137 eradicates drug resistant cancer stem cells and potentiates efficacy of gemcitabine in preclinical models of pancreatic cancer. Oncotarget $\mathbf{5}$ : 11038-11053, 2014.

CADILI A, KNETEMAN N: The role of macrophages in xenograft rejection. Transplant Proc 40: 3289-3293, 2008.

CARNERO A, BLANCO-APARICIO C, KONDOH H, LLEONART ME, MARTINEZ-LEAL JF, MONDELLO C, SCOVASSI AI, BISSON WH, AMEDEI A, ROY R, ET AL.: Disruptive chemicals, senescence and immortality. Carcinogenesis 36 (Suppl. 1): S19-S37, 2015.

COLLISSON EA, SADANANDAM A, OLSON P, GIBB WJ, TRUITT M, GU S, COOC J, WEINKLE J, KIM GE, JAKKULA L, FEILER HS, KO AH, OLSHEN AB, DANENBERG KL, TEMPERO MA, SPELLMAN PT, HANAHAN D, GRAY JW: Subtypes of pancreatic ductal adenocarcinoma and their differing responses to therapy. Nat Med 17: 500-503, 2011.

DE ANGELIS R, SANT M, COLEMAN MP, FRANCISCI S, BAILI P, PIERANNUNZIO D, TRAMA A, VISSER O, BRENNER H, ARDANAZ E, ET AL.: Cancer survival in Europe 1999-2007 by country and age: results of EUROCARE-5-a population-based study. Lancet Oncol 15: 23-34, 2014.

DHALIWAL A, VLACHOSTERGIOS PJ, OIKONOMOU KG, MOSHENYAT Y: Fecal DNA testing for colorectal cancer screening: Molecular targets and perspectives. World J Gastrointest Oncol 7: 178-183, 2015.

DIPERSIO LP: Regional growth differences of human tumour xenografts in nude mice. Lab Anim 15: 179-180, 1981.

ELLINGHAUS P, HEISLER I, UNTERSCHEMMANN K, HAERTER M, BECK H, GRESCHAT S, EHRMANN A, SUMMER H, FLAMME I, OEHME F, THIERAUCH K, MICHELS M, HESS-STUMPP H, ZIEGELBAUER K: BAY 87-2243, a highly potent and selective inhibitor of hypoxia-induced gene activation has antitumor activities by inhibition of mitochondrial complex I. Cancer Med 2: 611-624, 2013.

FARROW JM, YANG JC, EVANS CP: Autophagy as a modulator and target in prostate cancer. Nat Rev Urol 11: 508-516, 2014.

FLANAGAN SP: 'Nude', a new hairless gene with pleiotropic effects in the mouse. Genet Res 8: 295-309, 1966.

FOGH J, FOGH JM, ORFEO T: One hundred and twenty-seven cultured human tumor cell lines producing tumors in nude mice. J Natl Cancer Inst 59: 221-226, 1977. 
FOGH J, ORFEO T, TISO J, SHARKEY FE, FOGH JM, DANIELS WP: Twenty-three new human tumor lines established in nude mice. Exp Cell Biol 48: 229-239, 1980.

GANGULY A, YANG H, CABRAL F: Paclitaxel-dependent cell lines reveal a novel drug activity. Mol Cancer Ther 9: 2914-2923, 2010.

GAZDAR AF, HIRSCH FR, MINNA JD: From mice to men and back: an assessment of preclinical model systems for the study of lung cancers. J Thorac Oncol 11: e88-e89, 2015.

GENG L, WANG X: Epstein-Barr Virus-associated lymphoproliferative disorders: experimental and clinical developments. Int J Clin Exp Med 8: 14656-14671, 2015.

GIOVANELLA BC, FOGH J: The nude mouse in cancer research. Adv Cancer Res 44: 69-120, 1985.

GRECO A, ALBANESE S, AULETTA L, MIRABELli P, ZANNETTI A, D'ALTERIO C, DI MARO G, ORLANDELLA FM, SALVATORE G, SORICELLI A, SALVATORE M: High-frequency ultrasound-guided injection for the generation of a novel orthotopic mouse model of human thyroid carcinoma. Thyroid 26: $552-558,2016$.

GUO S, LV L, SHEN Y, HU Z, HE Q, CHEN X: A nanoparticulate pre-chemosensitizer for efficacious chemotherapy of multidrug resistant breast cancer. Sci Rep 6: 21459, 2016.

HADDAD TC, YEE D: Of Mice and (wo)men: is this any way to test a new drug? J Clin Oncol 26: 830-832, 2008.

HE L, TIAN D-A, LI P-Y, HE X-X: Mouse models of liver cancer: progress and recommendations. Oncotarget 6: 23306-23322, 2015.

HIDALGO M, AMANT F, BIANKIN AV, BUDINSKÁ E, BYRNE AT, CALDAS C, CLARKE RB, DE JONG S, JONKERS J, MÆLANDSMO GM, ROMAN-ROMAN S, SEOANE J, TRUSOLINO L, VILLANUEVA A: Patient-derived xenograft models: an emerging platform for translational cancer research. Cancer Discov 4 : 998-1013, 2014.

HOFFMAN RM: Application of GFP imaging in cancer. Lab Invest 95: 432-452, 2015.

HOFFMAN RM: Orthotopic metastatic mouse models for anticancer drug discovery and evaluation: a bridge to the clinic. Invest New Drugs 17: 343-359, 1999.

HOLUB M: The nude mouse. ILAR J 34: 1-3, 1992.

HOUSMAN G, BYLER S, HEERBOTH S, LAPINSKA K, LONGACRE M, SNYDER N, SARKAR S: Drug resistance in cancer: an overview. Cancers 6: 1769-1792, 2014.

HUI KF, YEUNG PL, CHIANG AKS: Induction of MAPK- and ROS-dependent autophagy and apoptosis in gastric carcinoma by combination of romidepsin and bortezomib. Oncotarget 7: 4454-4467, 2016.

HWANG C-I, BOJ SF, CLEVERS H, TUVESON DA: Preclinical models of pancreatic ductal adenocarcinoma. J Pathol 238: 197-204, 2016.

JANG E, KIM E, SON H-Y, LIM E-K, LEE H, CHOI Y, PARK K, HAN S, SUH J-S, HUH Y-M, HAAM S: Nanovesicle-mediated systemic delivery of microRNA-34a for CD44 overexpressing gastric cancer stem cell therapy. Biomaterials 105: 12-24, 2016.

JEON J, NIM S, TEYRA J, DATTI A, WRANA JL, SIDHU SS, MOFFAT J, KIM PM: A systematic approach to identify novel cancer drug targets using machine learning, inhibitor design and high-throughput screening. Genome Med 6: 57, 2014.

JIANG Y-Y, SHANG L, SHI Z-Z, ZHANG T-T, MA S, LU C-C, ZHANG Y, HAO J-J, SHI C, SHI F, XU X, CAI Y, JIA X-M, ZHAN Q-M, WANG M-R: Microtubule-associated protein 4 is an important regulator of cell invasion/migration and a potential therapeutic target in esophageal squamous cell carcinoma. Oncogene 35 : 4846-4856, 2016.

KELLAND LR: Of mice and men: values and liabilities of the athymic nude mouse model in anticancer drug development. Eur J Cancer 40: 827-836, 2004.

KENMOGNE LC, AYAN D, ROY J, MALTAIS R, POIRIER D: The aminosteroid derivative RM-133 shows in vitro and in vivo antitumor activity in human ovarian and pancreatic cancers. PloS One 10: e0144890, 2015.

KHAN Z, KHAN AA, PRASAD GBKS, KHAN N, TIWARI RP, BISEN PS: Growth inhibition and chemoradiosensitization of head and neck squamous cell carcinoma (HNSCC) by survivin-siRNA lentivirus. Radiother Oncol 118: 359-368, 2016.

KHANNA C, HUNTER K: Modeling metastasis in vivo. Carcinogenesis 26: 513-523, 2005. 
KILLION JJ, RADINSKY R, FIDLER IJ: Orthotopic models are necessary to predict therapy of transplantable tumors in mice. Cancer Metastasis Rev 17: 279-284, 1998.

KIM B, KIM K, IM KH, KIM J-H, LEE JH, JEON P, BYUN H: Multiparametric MR imaging of tumor response to intraarterial chemotherapy in orthotopic xenograft models of human metastatic brain tumor. J Neurooncol 127: 243-251, 2016.

KIM S-L, TRANG KTT, KIM SH, KIM IH, LEE SO, LEE ST, KIM DG, KIM S-W: Parthenolide suppresses tumor growth in a xenograft model of colorectal cancer cells by inducing mitochondrial dysfunction and apoptosis. Int J Oncol 41: 1547-1553, 2012.

KUMARI S, IDREES D, MISHRA CB, PRAKASH A, WAHIDUZZAMAN, AHMAD F, HASSAN MI, TIWARI M: Design and synthesis of a novel class of carbonic anhydrase-IX inhibitor 1-(3-(phenyl/4-fluorophenyl)-7imino-3H-[1,2,3]triazolo[4,5d]pyrimidin 6(7H)yl)urea. J Mol Graph Model 64: 101-109, 2016.

VAN DER KUYL AC, VAN DEN BURG R, ZORGDRAGER F, DEKKER JT, MAAS J, VAN NOESEL CJ, GOUDSMIT J, CORNELISSEN M: Primary effect of chemotherapy on the transcription profile of AIDS-related Kaposi's sarcoma. BMC Cancer 2: 21, 2002.

LE DT, JAFFEE EM: Regulatory T-cell modulation using cyclophosphamide in vaccine approaches: a current perspective. Cancer Res 72: 3439-3444, 2012.

LIU Z, SUN Y, HONG H, ZHAO S, ZOU X, MA R, JIANG C, WANG Z, LI H, LIU H: 3-bromopyruvate enhanced daunorubicin-induced cytotoxicity involved in monocarboxylate transporter 1 in breast cancer cells. Am J Cancer Res 5: 2673-2685, 2015.

LUCEY BP, NELSON-REES WA, HUTCHINS GM: Henrietta Lacks, HeLa cells, and cell culture contamination. Arch Pathol Lab Med 133: 1463-1467, 2009.

MA Z, YANG Y, YANG G, WAN J, LI G, LU P, DU L: Iodine-125 induces apoptosis via regulating p53, microvessel density, and vascular endothelial growth factor in colorectal cancer. World J Surg Oncol 12: 222, 2014.

MAJUMDER S, CHARI ST, AHLQUIST DA: Molecular detection of pancreatic neoplasia: current status and future promise. World J Gastroenterol 21: 11387-11395, 2015.

MARANGONI E, POUPON M-F: Patient-derived tumour xenografts as models for breast cancer drug development. Curr Opin Oncol 26: 556-561, 2014.

MECKLENBURG L, TYCHSEN B, PAUS R: Learning from nudity: lessons from the nude phenotype. Exp. Dermatol. 14: 797-810, 2005.

MEYERROSE TE, HERRBRICH P, HESS DA, NOLTA JA: Immune-deficient mouse models for analysis of human stem cells. Biotechniques 35: 1262-1272, 2003.

MINI E, NOBILI S, CACIAGLI B, LANDINI I, MAZZEI T: Cellular pharmacology of gemcitabine. Ann Oncol 17 (Suppl. 5): v7-v12, 2006.

MUKHTAR S, WOODHOUSE C: The management of cyclophosphamide-induced haematuria. BJU Int 105: $908-912$, 2010.

NÖLTING S, GIUBELLINO A, TAYEM Y, YOUNG K, LAUSEKER M, BULLOVA P, SCHOVANEK J, ANVER M, FLIEDNER S, KORBONITS M, GÖKE B, VLOTIDES G, GROSSMAN A, PACAK K: Combination of 13-Cis retinoic acid and lovastatin: marked antitumor potential in vivo in a pheochromocytoma allograft model in female athymic nude mice. Endocrinology 155: 2377-2390, 2014.

OH J-H, JUNG S-H, HONG S-J, RHYU M-G: DNA methylation as surrogate marker for gastric cancer. J Cancer Prev 20: 172-178, 2015.

PACAK K, SIROVA M, GIUBELLINO A, LENCESOVA L, CSADEROVA L, HUDECOVA S, KRIZANOVA O: $\mathrm{NF}-\kappa \mathrm{B}$ inhibition significantly upregulates the norepinephrine transporter system, causes apoptosis in pheochromocytoma cell lines and prevents metastasis in an animal model. Int J Cancer 131: 2445-2455, 2012.

PANTELOURIS EM: Athymic development in the mouse. Differ Res Biol Divers 1: 437-450, 1973.

PASTOREK J, PASTOREKOVA S: Hypoxia-induced carbonic anhydrase IX as a target for cancer therapy: from biology to clinical use. Semin Cancer Biol 31: 52-64, 2015.

POMMIER Y: Drugging topoisomerases: lessons and challenges. ACS Chem Biol 8: 82-95, 2013. 
PROWSE DM, LEE D, WEINER L, JIANG N, MAGRO CM, BADEN HP, BRISSETTE JL: Ectopic expression of the nude gene induces hyperproliferation and defects in differentiation: implications for the self-renewal of cutaneous epithelia. Dev Biol 212: 54-67, 1999.

RAHAL OM, NIE L, CHAN L-C, LI C-W, HSU Y-H, HSU J, YU D, HUNG M-C: Selective expression of constitutively active pro-apoptotic protein BikDD gene in primary mammary tumors inhibits tumor growth and reduces tumor initiating cells. Am J Cancer Res 5: 3624-3634, 2015.

RODRIGUEZ J, BOUCHER F, LEQUEUX C, JOSSET-LAMAUGARNY A, ROUYER O, ARDISSON O, RUTSCHI H, SIGAUDO-ROUSSEL D, DAMOUR O, MOJALLAL A: Intradermal injection of human adipose-derived stem cells accelerates skin wound healing in nude mice. Stem Cell Res Ther 6: 241, 2015.

ROMANO R, PALAMARO L, FUSCO A, IANNACE L, MAIO S, VIGLIANO I, GIARDINO G, PIGNATA C: From murine to human nude/SCID: the thymus, T-cell development and the missing link. Clin Dev Immunol 2012: $467101,2012$.

ROULEAU C, GIANOLIO DA, SMALE R, ROTH SD, KRUMBHOLZ R, HARPER J, MUNROE KJ, GREEN TL, HORTEN BC, SCHMID SM, TEICHER BA: Anti-endosialin antibody-drug conjugate: potential in sarcoma and other malignancies. Mol Cancer Ther 14: 2081-2089, 2015.

RUIZ P, MALDONADO P, HIDALGO Y, GLEISNER A, SAUMA D, SILVA C, SAEZ JJ, NUÑEZ S, ROSEMBLATT M, BONO MR: Transplant tolerance: new insights and strategies for long-term allograft acceptance. Clin Dev Immunol 2013: 210506, 2013.

SAXENA M, CHRISTOFORI G: Rebuilding cancer metastasis in the mouse. Mol Oncol 7: 283-296, 2013.

SCHUH JCL: Trials, tribulations, and trends in tumor modeling in mice. Toxicol Pathol 32: 53-66, 2004.

SCHWEITZER BI, DICKER AP, BERTINO JR: Dihydrofolate reductase as a therapeutic target. FASEB $J \mathbf{4}$ : 2441-2452, 1990.

SCOTT CL, MACKAY HJ, HALUSKA P: Patient-derived xenograft models in gynecological malignancies. Am Soc Clin Oncol Educ Book. 3: e258-e266, 2014.

SEICEAN A, PETRUSEL L, SEICEAN R: New targeted therapies in pancreatic cancer. World J Gastroenterol 21: 6127-6145, 2015.

SHAW TJ, SENTERMAN MK, DAWSON K, CRANE CA, VANDERHYDEN BC: Characterization of intraperitoneal, orthotopic, and metastatic xenograft models of human ovarian cancer. Mol Ther 10: 1032-1042, 2004.

SHULTZ LD, LYONS BL, BURZENSKI LM, GOTT B, CHEN X, CHALEFF S, KOTB M, GILLIES SD, KING M, MANGADA J, GREINER DL, HANDGRETINGER R: Human lymphoid and myeloid cell development in NOD/LtSz-scid IL2R $\gamma$ null mice engrafted with mobilized human hemopoietic stem cells. J Immunol 174: 6477-6489, 2005.

SHULTZ LD, PEARSON T, KING M, GIASSI L, CARNEY L, GOTT B, LYONS B, ROSSINI AA, GREINER DL: Humanized NOD/LtSz-scid IL2 receptor common gamma chain knockout mice in diabetes research. Ann NY Acad Sci 1103: 77-89, 2007.

SHULTZ LD, BREHM MA, GARCIA-MARTINEZ JV, GREINER DL: Humanized mice for immune system investigation: progress, promise and challenges. Nat Rev Immunol 12: 786-798, 2012.

SHULTZ LD, GOODWIN N, ISHIKAWA F, HOSUR V, LYONS BL, GREINER DL: Human cancer growth and therapy in NOD/SCID/IL2R $\gamma$ null (NSG) mice. Cold Spring Harb Protoc 2014: 694-708, 2014.

SIMMONS JK, HILDRETH BE, SUPSAVHAD W, ELSHAFAE SM, HASSAN BB, DIRKSEN WP, TORIBIO RE, ROSOL TJ: Animal models of bone metastasis. Vet Pathol 52: 827-841, 2015.

SINGH AV, XIAO D, LEW KL, DHIR R, SINGH SV: Sulforaphane induces caspase-mediated apoptosis in cultured PC-3 human prostate cancer cells and retards growth of PC-3 xenografts in vivo. Carcinogenesis 25: 83-90, 2004.

STAKLEFF KDS, VON GRUENIGEN VE: Rodent models for ovarian cancer research. Int J Gynecol Cancer 13: 405-412, 2003.

SUN L, LI H, LUO H, ZHAO Y: Thymic epithelial cell development and its dysfunction in human diseases. Biomed Res Int 2014: 206929, 2014. 
TACAR O, SRIAMORNSAK P, DASS CR: Doxorubicin: an update on anticancer molecular action, toxicity and novel drug delivery systems. J Pharm Pharmacol 65: 157-170, 2013.

TEICHER BA: Tumor models for efficacy determination. Mol Cancer Ther 5: 2435-2443, 2006.

TENTLER JJ, TAN AC, WEEKES CD, JIMENO A, LEONG S, PITTS TM, ARCAROLI JJ, MESSERSMITH WA, ECKHARDT SG: Patient-derived tumour xenografts as models for oncology drug development. Nat Rev Clin Oncol 9: 338-350, 2012.

TESTERMAN TL, MORRIS J: Beyond the stomach: An updated view of Helicobacter pylori pathogenesis, diagnosis, and treatment. World J Gastroenterol 20: 12781-12808, 2014.

THORN CF, OSHIRO C, MARSH S, HERNANDEZ-BOUSSARD T, MCLEOD H, KLEIN TE, ALTMAN RB: Doxorubicin pathways: pharmacodynamics and adverse effects. Pharmacogenet Genomics 21: 440-446, 2011.

TOMAYKO MM, REYNOLDS CP: Determination of subcutaneous tumor size in athymic (nude) mice. Cancer Chemother Pharmacol 24: 148154, 1989.

TORRENTS E: Ribonucleotide reductases: essential enzymes for bacterial life. Front Cell Infect Microbiol 4: 52 , 2016.

WALKO CM, LINDLEY C: Capecitabine: a review. Clin Ther 27: 23-44, 2005.

WANG J, HU W, WANG K, YU J, LUO B, LUO G, WANG W, WANG H, LI J, WEN J: Repertaxin, an inhibitor of the chemokine receptors CXCR1 and CXCR2, inhibits malignant behavior of human gastric cancer MKN45 cells in vitro and in vivo and enhances efficacy of 5-fluorouracil. Int J Oncol 8: 1341-1352, 2016.

WEIDERPASS E, PUKKALA E: Time trends in socioeconomic differences in incidence rates of cancers of gastrointestinal tract in Finland. BMC Gastroenterol 6: 41, 2006.

WEIGELT B, PETERSE JL, VAN'T VEER LJ: Breast cancer metastasis: markers and models. Nat Rev Cancer 5: 591-602, 2005.

VAN DER WEKKEN AJ, SABER A, HILTERMANN TJN, KOK K, VAN DEN BERG A, GROEN HJM: Resistance mechanisms after tyrosine kinase inhibitors afatinib and crizotinib in non-small cell lung cancer, a review of the literature. Crit Rev Oncol Hematol 100: 107-116, 2016.

WONG PT, CHOI SK: Mechanisms and implications of dual-acting methotrexate in folate-targeted nanotherapeutic delivery. Int J Mol Sci 16: 1772-1790, 2015.

WORKMAN P, ABOAGYE EO, BALKWILL F, BALMAIN A, BRUDER G, CHAPLIN DJ, DOUBLE JA, EVERITT J, FARNINGHAM DA, GLENNIE MJ, KELLAND LR, ROBINSON V, STRATFORD IJ, TOZER GM, WATSON S, WEDGE SR, ECCLES SA: Guidelines for the welfare and use of animals in cancer research. $\mathrm{Br}$ J Cancer 102: 1555-1577, 2010.

WYATT MD, WILSON DM: Participation of DNA repair in the response to 5-fluorouracil. Cell Mol Life Sci 66: 788-799, 2009.

XIONG Y, KOTIAN S, ZEIGER MA, ZHANG L, KEBEBEW E: miR-126-3p inhibits thyroid cancer cell growth and metastasis, and is associated with aggressive thyroid cancer. PloS One 10: e0130496, 2015.

XU Y, VILLALONA-CALERO MA: Irinotecan: mechanisms of tumor resistance and novel strategies for modulating its activity. Ann Oncol 13: 1841-1851, 2002.

YANG H, YIN P, SHI Z, MA Y, ZHAO C, ZHENG J, CHEN T: Sinomenine, a COX-2 inhibitor, induces cell cycle arrest and inhibits growth of human colon carcinoma cells in vitro and in vivo. Oncol Lett 11: 411-418, 2016.

YAO Y, ZHOU Y, SU X, DAI L, YU L, DENG H, GOU L, YANG J: Establishment and characterization of intraperitoneal xenograft models by co-injection of human tumor cells and extracellular matrix gel. Oncol Lett 10: 3450-3456, 2015.

YARBRO JW: Mechanism of action of hydroxyurea. Semin Oncol 19: 1-10, 1992.

YEON KIM D, YOUNG PARK E, CHANG E, KANG H-G, KOO Y, JI LEE E, YEONG KO J, KYUNG KONG H, CHUN K-H, HOON PARK J: A novel miR-34a target, protein kinase D1, stimulates cancer stemness and drug resistance through GSK3/ $\beta$-catenin signaling in breast cancer. Oncotarget 7: 14791-14802, 2016.

YIN T, WANG G, YE T, WANG Y: Sulindac, a non-steroidal anti-inflammatory drug, mediates breast cancer inhibition as an immune modulator. Sci Rep 6: 19534, 2016.

ZHANG N, YIN Y, XU S-J, CHEN W-S: 5-Fluorouracil: mechanisms of resistance and reversal strategies. Mol Basel Switz 13: 1551-1569, 2008. 